\title{
Front Matter: Volume 9854
}

, "Front Matter: Volume 9854," Proc. SPIE 9854, Image Sensing Technologies: Materials, Devices, Systems, and Applications III, 985401 (1 July 2016); doi: 10.1117/12.2231207

SPIE Event: SPIE Commercial + Scientific Sensing and Imaging, 2016, Baltimore, MD, United States 


\section{PROCEEDINGS OF SPIE}

\section{Image Sensing Technologies: Materials, Devices, Systems, and Applications III}

Nibir K. Dhar

Achyut K. Dutta

Editors

20-21 April 2016

Baltimore, Maryland, United States

Sponsored and Published by

SPIE

Volume 9854 
The papers in this volume were part of the technical conference cited on the cover and title page. Papers were selected and subject to review by the editors and conference program committee. Some conference presentations may not be available for publication. Additional papers and presentation recordings may be available online in the SPIE Digital Library at SPIEDigitallibrary.org.

The papers reflect the work and thoughts of the authors and are published herein as submitted. The publisher is not responsible for the validity of the information or for any outcomes resulting from reliance thereon.

Please use the following format to cite material from these proceedings:

Author(s), "Title of Paper," in Image Sensing Technologies: Materials, Devices, Systems, and Applications III, edited by Nibir K. Dhar, Achyut K. Dutta, Proceedings of SPIE Vol. 9854 (SPIE, Bellingham, WA, 2016) Six-digit Article CID Number.

ISSN: 0277-786X

ISSN: 1996-756X (electronic)

ISBN: 9781510600959

Published by

SPIE

P.O. Box 10, Bellingham, Washington 98227-0010 USA

Telephone +1 3606763290 (Pacific Time) · Fax +1 3606471445

SPIE.org

Copyright (C) 2016, Society of Photo-Optical Instrumentation Engineers.

Copying of material in this book for internal or personal use, or for the internal or personal use of specific clients, beyond the fair use provisions granted by the U.S. Copyright Law is authorized by SPIE subject to payment of copying fees. The Transactional Reporting Service base fee for this volume is $\$ 18.00$ per article (or portion thereof), which should be paid directly to the Copyright Clearance Center (CCC), 222 Rosewood Drive, Danvers, MA 01923. Payment may also be made electronically through CCC Online at copyright.com. Other copying for republication, resale, advertising or promotion, or any form of systematic or multiple reproduction of any material in this book is prohibited except with permission in writing from the publisher. The CCC fee code is 0277-786X/16/\$18.00.

Printed in the United States of America.

Publication of record for individual papers is online in the SPIE Digital Library.

\section{SPIE. DIGITAL}

Paper Numbering: Proceedings of SPIE follow an e-First publication model. A unique citation identifier (CID) number is assigned to each article at the time of publication. Utilization of CIDs allows articles to be fully citable as soon as they are published online, and connects the same identifier to all online and print versions of the publication. SPIE uses a six-digit CID article numbering system structured as follows:

- The first four digits correspond to the SPIE volume number.

- The last two digits indicate publication order within the volume using a Base 36 numbering system employing both numerals and letters. These two-number sets start with 00, 01, 02, 03, 04, $05,06,07,08,09,0 A, 0 B \ldots$ OZ, followed by 10-1Z, 20-2Z, etc. The CID Number appears on each page of the manuscript. 


\title{
Contents
}

\author{
$\checkmark$ Authors \\ vii Conference Committee
}

\section{SESSION 1 NOVEL IMAGE SENSING TECHNOLOGIES AND APPLICATIONS I}

985405 Recent progress in avalanche photodiodes for sensing in the IR spectrum (Invited Paper) [9854-4]

985406 Broadband antireflection with curved surface nano-pyramids for image sensing devices [9854-5]

985407 Development of nanostructured antireflection coatings for EO/IR sensor applications [9854-6]

985408 Development of silicon-germanium visible-near infrared arrays [9854-7]

985409 High performance digital read out integrated circuit (DROIC) for infrared imaging [9854-8]

9854 OA Overview of detector technologies for EO/IR sensing applications (Invited Paper) [9854-9]

SESSION 2 NOVEL IMAGE SENSING TECHNOLOGIES AND APPLICATIONS II

9854 OB Dislocation reduction in HgCdTe grown on CdTe/Si (Invited Paper) [9854-10]

9854 OC Extended SWIR imaging sensors for hyperspectral imaging applications [9854-1 1]

9854 OD Development of graphene based detectors for EO/ IR applications [9854-12]

9854 OE Fast cooldown coaxial pulse tube microcooler [9854-13]

9854 OF Strategic options towards an affordable high-performance infrared camera [9854-14]

$9854 \mathrm{OH}$ Detectors and focal plane modules for weather instruments (Invited Paper) [9854-16]

\section{SESSION 3 NOVEL THZ IMAGE SENSING TECHNOLOGIES AND APPLICATIONS I}

9854 OK Independent component analysis applications on THz sensing and imaging [9854-19]

$9854 \mathrm{OL}$ Evolution of $\mathrm{THz}$ impulse imaging radar to $1550 \mathrm{~nm}$ photoconductive switches (Invited Paper) [9854-20] 
9854 ON Handheld THz security imaging (Invited Paper) [9854-22]

9854 OQ Terahertz sensing with waveguides (Invited Paper) [9854-25]

9854 OR Terahertz imaging with quantum cascade lasers (Invited Paper) [9854-26]

\section{POSTER SESSION}

9854 OT Analysis and implementation of the foveated vision of the raptor eye [9854-27]

9854 OU Characterization of electromechanical actuator implemented to phase-shift system applied to a Michelson interferometer [9854-28]

9854 OV Remote application for spectral collection [9854-29]

9854 OW Characterization of internal geometry / covered surface defects with a visible light sensing system [9854-31]

9854 OX Alignment issues, correlation techniques and their assessment for a visible light imagingbased 3D printer quality control system [9854-32]

9854 OY Lithographic VCSEL array multimode and single mode sources for sensing and 3D imaging [9854-34]

9854 OZ Binary CMOS image sensor with a gate/body-tied MOSFET-type photodetector for highspeed operation [9854-35]

$985410 \quad$ Novel high performance multispectral photodetector and its performance [9854-36]

985411 A study on optical coherence tomography using high frequency swept source [9854-37]

985413 Enablement of scientific remote sensing missions with in-space 3D printing [9854-39]

985414 Visualization of coke state in hydraulic decoking process [9854-40]

985415 Infrared optical and electronic properties in low tellurium doped GaSb substrates for SLS FPA applications [9854-42]

985416 New high performance Si for optical devices [9854-43] 
Roodenko, K., 15

Roth, E., OE

Rouse, Caitlin, 08

Saito, E., OE

Sako, R., 16

Shin, Jang-Kyoo, $0 Z$

Shrestha, Anil, 06

Sieck, A., OC

Smith, D. S., $\mathrm{OH}$

Sood, Ashok K., 07, 08, 0A, OD

Steele, R. J., OV

Straub, Jeremy, OW, 0X, 13

Sung, S., OL

Takase, K., 16

Tauber, Michael J., OT

Taylor, Z. D., OL

Tenma, T., 16

Tong, Xinglin, 11, 14

Tucker, F., OY

Tzeng, Nigel H., OV

Vargason, K. W., 15

Weber, A., OC

Welser, Roger E., 07, 0A

Wen, Hongqiao, 11

Wendler, J., OC

Wijewarnasuriya, Priyalal S., 07, 08, OA, OB, OD

Woodson, M. E., 05

Xiong, Jiaguo, 14

Yang, $X ., O Y$

Zeller, John W., 08, OA, OD

Zhang, Cui, 14

Zhang, W.-D., OL

Zhang, Y. , OY

Zhao, Minli, 11

Zimmerman, Ian A., OR 


\title{
Conference Committee
}

\author{
Symposium Chair
}

Ming C. Wu, University of California, Berkeley (United States)

Symposium Co-chair

Majid Rabbani, Eastman Kodak Company (United States)

Conference Chairs

Nibir K. Dhar, U.S. Army Night Vision \& Electronic Sensors

Directorate (United States)

Achyut K. Dutta, Banpil Photonics, Inc. (United States)

Conference Program Committee

Homayoon Ansari, Jet Propulsion Laboratory (United States)

Arvind I. D'Souza, DRS Sensors and Targeting Systems, Inc.

(United States)

Ravi Dutt, Booz Allen Hamilton Inc. (United States)

Michael D. Gerhold, U.S. Army Research Office (United States)

John E. Hubbs, Ball Aerospace and Technologies Corporation (United States)

Margaret Kim, The University of Alabama (United States)

Nobuhiko P. Kobayashi, University of California, Santa Cruz (United States)

Sanjay Krishna, The University of New Mexico (United States)

Rihito Kuroda, Tohoku University (Japan)

Robert Olah, Banpil Photonics, Inc. (United States)

Willie Padilla, Duke University (United States)

Adam Piotrowski, VIGO Systems S.A. (Poland)

Siva Sivananthan, EPIR Technologies, Inc. (United States)

Krishna Swaminathan, Intel Corporation (United States)

Priyalal S. Wijewarnasuriya, U.S. Army Research Laboratory

(United States)

\section{Session Chairs}

1 Novel Image Sensing Technologies and Applications I

Nibir K. Dhar, U.S. Army Night Vision \& Electronic Sensors Directorate (United States)

Achyut K. Dutta, Banpil Photonics, Inc. (United States) 
2 Novel Image Sensing Technologies and Applications II

Achyut K. Dutta, Banpil Photonics, Inc. (United States)

Nibir K. Dhar, U.S. Army Night Vision \& Electronic Sensors Directorate (United States)

3 Novel THz Image Sensing Technologies and Applications I

Margaret Kim, The University of Alabama (United States)

Willie Padilla, Duke University (United States)

4 Novel THz Image Sensing Technologies and Applications II

Willie Padilla, Duke University (United States)

Margaret Kim, The University of Alabama (United States) 